\title{
TAX BURDEN OF AGRICULTURAL ENTERPRISES IN UKRAINE
}

Serhii Kostornoi ${ }^{\mathrm{a}^{*}}$, Olena Yatsukh ${ }^{\mathrm{a}}$, Volodymyr Tsap ${ }^{\mathrm{a}}$, Ivan Demchenko ${ }^{\mathrm{a}}$, Natalia Zakharova $^{\mathrm{a}}$, Maksym Klymenko ${ }^{\mathrm{b}}$, Oleksandr Labenko ${ }^{\mathrm{b}}$, Victoriya Baranovska ${ }^{\mathrm{c}}$, Zbigniew Daniel $^{\mathrm{d}}$, Wioletta Tomaszewska-Górecka ${ }^{\mathrm{e}}$

a Department of Finance, Banking and Insurance, Dmytro Motornyi Tavria State Agrotechnological University, Melitopol, Ukraine, e-mail: serhii.kostornoi@tsatu.edu.ua, ORCID 0000-0003-0477636X, e-mail: olena.yatsukh@tsatu.edu.ua, ORCID 0000-0002-8007-2009, e-mail: volodymyr.tsap @ tsatu.edu.ua, ORCID 0000-0001-8059-3122, e-mail: ivan.demchenko@tsatu.edu.ua, ORCID 00000002-0358-3016, e-mail: natalia.zakharova@tsatu.edu.ua, ORCID 0000-0002-5491-492X.

b Faculty of Economics, National University of Life and Environmental Sciences of Ukraine, Kyiv, Ukraine, e-mail: maxklymenko@ nubip.edu.ua, ORCID 0000-0001-6481-9945, labenko@ nubip.edu.ua, ORCID 0000-0001-9192-9891

c Director of Sales, Ewan, Sharjah, UAE, e-mail: wte.inter@gmail.com

d Department of Production Engineering, Logistics and Applied Computer Science, University of Agriculture in Krakow, Balicka 116B, 30-149 Krakow, Poland, e-mail: zbigniew.daniel@urk.edu.pl, ORCID 0000-0001-5507-8911

e Eastern European State College of Higher Education in Przemysl, Książąt Lubomirskich 6, 37-700 Przemysl, Poland, e-mail: w.tomaszewska-gorecka@pwsw.eu.

*Corresponding author: e-mail: serhii.kostornoi@tsatu.edu.ua

\begin{tabular}{|c|c|}
\hline ARTICLE INFO & ABSTRACT \\
\hline $\begin{array}{l}\text { Article history: } \\
\text { Received: August } 2021 \\
\text { Received in the revised form: } \\
\text { September } 2021 \\
\text { Accepted: October } 2021 \\
\end{array}$ & $\begin{array}{l}\text { Agriculture is one of the leading sectors of the Ukrainian economy, and } \\
\text { the state pays special attention to its development. One of directions of } \\
\text { the state's support for agriculture is implementation of tax preferences } \\
\text { due to which agricultural enterprises have a lower tax burden. The op- } \\
\text { timal level of the tax burden is an important factor in ensuring the pos- }\end{array}$ \\
\hline $\begin{array}{l}\text { Keywords: } \\
\text { taxation, } \\
\text { tax burden, } \\
\text { agricultural producers, } \\
\text { simplified taxation system, } \\
\text { value added tax }\end{array}$ & $\begin{array}{l}\text { itive dynamics of business activity in agriculture, as well as socio-po- } \\
\text { litical stability. The objective of the article is to determine the impact } \\
\text { of recent changes in the Ukrainian tax legislation on the tax burden of } \\
\text { agricultural enterprises, as well as the possible impact of current draft } \\
\text { laws. The article examines features of the tax legislation in Ukrainewith } \\
\text { regard to agricultural producers and its changes in recent years - in- } \\
\text { creasing a single tax rate, introduction of indexation of land regulatory, } \\
\text { monetary valuation, abolition of the special regime of a value added tax. } \\
\text { The advantages and disadvantages of using a simplified taxation system } \\
\text { by agricultural enterprises are considered. the study's outcome com- } \\
\text { prises recommendations for agricultural enterprises to choose a tax sys- } \\
\text { tem with the lowest tax burden, as well as recommendations for im- } \\
\text { proving the tax legislation of Ukraine using preferential VAT rates for } \\
\text { agricultural enterprises and a tax on withdrawn capital. }\end{array}$ \\
\hline
\end{tabular}




\section{Introduction}

The agro-industrial branch is an important component of Ukraine's economy - it forms a significant share of gross domestic product, it is responsible for the state's food security, is an important component of export potential. The country must create optimal conditions for agricultural development, in particular, reduce the tax burden on agricultural enterprises. We need an effective system of the state support for agricultural producers, which would help to increase production, form an optimal industry structure, improve product quality, implement modern technologies, develop rural areas, etc.

Taxation of agricultural enterprises, tax burden, special tax regimes and the main directions of their optimization is the subject of research by many Ukrainian scientists (Baranova and Dubovik, 2013, Demyanenko, 1999, Zhuk, 2011, Kostornoi, 2014, Krysovaty and Vasylevska, 2013, Prokopchuk, 2014, Tulush, 2016, Tsap, 2018, Yatsukh, 2015, Kovalenko et al., 2021a, Kovalenko et al., 2021b, Trusova et al., 2020, Shevchuk and Kopych, 2018, Odintsov et al., 2020, Halushchak et al., 2019).

Foreign authors also pay great attention to creation of an effective tax system and optimization of the tax burden (Rymanov, 2017, Hogan, 2012, Vasiljevic, 2016, Siroky et al., 2016, Slemrod, 1990, Alm and El-Ganainy, 2013, Uryszek, 2018, Troilo et al., 2017, Wach, 2006, McGee, 2008).

The aim of the research was to determine the impact of recent changes in the Ukraninian tax legislation on the tax burden of agricultural enterprises, as well as the possible impact of current draft laws.

\section{Material and Methods}

The study used current legislative and regulatory documents of Ukraine, expert assessments of managers and specialists of agricultural enterprises of Ukraine, data of the State Statistics Service of Ukraine on financial indicators of agricultural enterprises of Ukraine for 2014-2019, data of the Verkhovna Rada of Ukraine on registered draft laws on tax improvement in the agricultural sector of the economy.

To assess the impact of taxation on the agricultural sector of the economy, the following indicators were selected:

- Financial results before taxation - the difference between the sum of the financial result from operating activities (including the income from equity and other financial income) and expenses (including financial and other expenses),

- Net profit - the part of the balance sheet profit of the enterprise, which remains at its disposal after payment of taxes, fees, deductions and other mandatory payments to the budget,

- The share of profitable enterprises - the number of profitable enterprises divided by the total number of enterprises,

- Profitability of operating activities - the ratio of profit from operating activities to the amount of operating expenses.

The decrease in these indicators reflects the increase in the tax burden. 
Tax burden...

\section{Results and Discussion}

The optimal level of the tax burden is an important factor ensuring positive dynamics of business activity in the country, development of production and economy as a whole, as well as socio-political stability.

Scholars consider the tax burden at the state level, the tax burden on enterprises, the tax burden on citizens.

Modern scientists understand the "tax burden of the enterprise" as:

- the amount of tax paid byan enterprise to the budget,

- the share of taxes in the income of an enterprise,

- the impact of taxation on the financial performance of an enterprise.

The theoretical generalization of the problem of tax burden and determination of the optimal level of taxation was carried out in the mid-70s of the twentieth century by American scientist A. Laffer (Laffer and Seymour, 1979). He argued that excessive taxation negatively affects business and investment activities and ultimately leads to lower tax revenues. A. Laffer investigated the relationship between the level of taxation (tax rate) and individual adaptation of taxpayers (the tax revenue amount). Withdrawal by the state in the form of taxes of a significant amount of income in the amount of $40-50 \%$ is the limit beyond which incentives for entrepreneurial initiative and expansion of production are eliminated.

The largest part of the tax burden of agricultural enterprises in Ukraine is formed by the following taxes, fees, mandatory payments:

- single tax (group IV),

- value added tax (VAT),

- taxes on the salary fund (personal income tax, military duty, single contribution to compulsory social insurance),

- corporate income tax,

- a land tax.

A feature of the tax system of Ukraine is the possibility of agricultural enterprises applying a simplified system of taxation, which involves the calculation of a single tax instead of a number of other taxes and fees.

Agricultural enterprises can be referred to the IV group of payers if they have a share of agricultural production in income for the previous tax (reporting) year equal to or exceeding75 percent (Tax Code of Ukraine, 2021).

Such enterprises - payers of the single tax are released from the obligation to charge, pay and submit tax returns on the following taxes and fees:

- corporate income tax,

- property tax (in part of the land tax), except for the land tax for land plots that are not used by the payers of the single tax of the IV group for conducting agricultural commodity production,

- rent for special use of water.

The object of taxation for single tax payers of the IV group is the area of agricultural lands (arable land, hayfields, pastures and perennial plantations) and / or lands of the water fund (inland reservoirs, lakes, ponds, reservoirs), which is owned by an agricultural producer or provided to him for use, including on lease (Tax Code of Ukraine, 2021).

Land ownership or use rights must be formalized and registered in accordance with the law. 
The tax base is the normative monetary assessment of one hectare of agricultural land (arable land, hayfields, pastures and perennials), taking into account the indexation coefficient.

The basis for calculating the single tax for group IV payers is the data of the state land cadastre and / or data from the state register of real rights to immovable property.

The reporting period is a calendar year (Tax Code of Ukraine, 2021).

Payers of the single tax of the IV group:

- independently calculate the amount of tax annually as of January 1 , and not later than on February 20 of the current year submit the tax return for the current year to the relevant supervisory authority at the the taxpayer's venue and the venue of the land,

- pay the tax quarterly within 30 calendar days following the last calendar day of the tax (reporting) quarter, in the following amounts: in the I quarter - $10 \%$, in II - $10 \%$, in III $-50 \%$, in IV - $30 \%$ (Tax Code of Ukraine, 2021).

The dynamics of changes in the single tax rates (until 2015 - a fixed agricultural tax) are shown in Table 1.

Table 1.

Single tax rates for taxpayers of group IV (fixed agricultural tax) for 2005-2021

\begin{tabular}{lccccc}
\hline & \multicolumn{5}{c}{ Tax rates, (\%) } \\
\cline { 2 - 6 } Land type & $2005-2013$ & 2014 & 2015 & 2016 & $2017-2021$ \\
\hline Arable land, hayfields and & 0.15 & 0.15 & 0.45 & 0.81 & 0.95 \\
pastures & 0.09 & 0.09 & 0.27 & 0.49 & 0.57 \\
\hline Perennial plantings & &
\end{tabular}

In Ukraine, since 2015, there has been a tendency to increase the single tax rate for agricultural producers, which makes the simplified taxation system less profitable for enterprises.

In addition, the amount of the single tax for agricultural enterprises has increased significantly due to the fact that since 2015, when calculating the tax base, the indexation of the normative monetary valuation of the land is used - a coefficient of 3,997 is applied for 1995$2014,1,124$ - for 2016, and an additional coefficient of 1.756 for arable land.

The combined effect of these factors has led to an increase in the amount of the single tax in 2020 compared to 2014 by 50 times for companies specialized in crop production.

The application of a single tax for the agricultural sector of the economy has its advantages and disadvantages.

Advantages:

- reduction of the tax burden on agricultural enterprises in general (especially by 2015), improvement of their financial results,

- simplification of accounting and reporting by agricultural enterprises, reduction of time spent on document management. 
Tax burden...

Disadvantages:

- reduction of revenues to local budgets,

- the need to pay a fixed amount of tax, even if the activities of the company are unprofitable,

- dissemination of tax evasion schemes,

- negligence in accounting for income and expenses of many enterprises, which leads to distortion of reporting indicators.

Legislative changes to the procedure for calculating the single tax have reduced the attractiveness of the simplified taxation system for agricultural enterprises (the fourth group of single tax payers) and their consideration of an alternative - the general taxation system and the third group of single tax payers.

When considering such a decision in order to reduce the tax burden, they need to consider the following factors:

\section{Expected amount of income and profit:}

- for the third group of single tax payers the annual income limit is set at UAH 7 million (EUR 228000),

- under the general system of taxation, income tax is levied at the rate of $18 \%$,

- enterprises that expect high profits, it is advisable to choose a single tax of the fourth group,

- enterprises with low expected profits and unprofitable enterprises should switch to the general system of taxation,

\section{Area and monetary valuation of land:}

- for single tax payers of the fourth group, the amount of the single tax directly depends on the area and monetary value of agricultural land, taking into account both own land and leased,

- enterprises specializing in animal husbandry have a small area of agricultural land and significant profitability, it is advisable to use a single tax of the fourth group,

\section{Specialization of the enterprise:}

- payers of the single tax of the fourth group may be agricultural producers - legal entities, regardless of organizational and legal form, in which the share of agricultural production for the previous tax (reporting) year is equal to or exceeds 75 percent,

- cannot be payers of the single tax of the fourth group:

- economic entities in which more than 50 percent of the income is received from the sale of agricultural products of own production and products of its processing constitute income from the sale of ornamental plants, wild animals and birds, fur products and fur,

- business entities engaged in the production of excisable goods, except for grape wine materials, produced at primary winemaking enterprises for secondary winemaking enterprises that use such wine materials for you-production of finished products,

- activities prohibited for single tax payers of the third group specified in paragraph 291.5 of the Tax Code (Tax Code of Ukraine, 2021), in particular:

- production, export, import, sale of excisable goods,

- extraction, sale of minerals, except for the sale of minerals of local importance. 


\section{Use of irrigation systems:}

- enterprises that actively use irrigation, it is advisable to choose a single tax of the fourth group, which provides for exemption from rent for special use of water,

\section{Amounts of dividends distributed among the owners of an enterprise:}

- dividends received from the enterprise - payers of corporate income tax are taxed by personal income tax atthe rate of $5 \%$, in other cases $-9 \%$,

\section{Relations with landlords - owners of land shares:}

- if the company rents land plots in the general system of taxation, the land tax is paid by the peasants-owners themselves - the company will have to increase the rent accordingly to prevent the loss of land,

- for enterprises - payers of the single tax of the fourth group, the single tax is paid from their own and leased lands, and the peasants do not pay the land tax,

\section{Presence of the tax debt:}

- taxpayers who on the day of filing the application for registration have a tax debt, except for bad tax debt, which arose as a result of force majeure, are not entitled to be single tax payers,

\section{The complexity of accounting, reporting:}

- accounting and reporting in the general system of taxation require more time.

- Reform of the single tax of the 4th group is considered by scientists and authors of bills in the context of the following areas:

- abolition of the single tax (the amount of the single tax does not depend on the profits of enterprises, and thus makes it possible to implement tax avoidance schemes),

- change in the procedure for calculating the tax base - the determination of the monetary valuation of the land is carried out by indexing the indicators of 1995 or According to the order of the Ministry of Agrarian Policy № 262 from 23.05.2017 (as amended by order № 605 from 18.12.2018), and after lifting the moratorium on the sale of agricultural land, the procedure for determination of the tax base may be revised to take into account land prices that will be formed,

- reduction of the list of payers of the single tax of the 4th group due to the increase of requirements to them, abolition of privileges to highly profitable branches of agriculture:

- establishment by the object of taxation exclusively of own land plots, and the land tax is paid from the leased ones,

- establishing a requirement for the share of livestock,

- establishing a requirement for the maximum size,

- increase of single tax rates (introduction of increased rates in case the total area of land owned or used by an agricultural producer exceeds 100 hectares),

- differentiation of tax rates depending on the type of activity.

In addition to the single tax, value added tax has a significant impact on the tax burden on agricultural enterprises.

Since 1998, the agricultural sector has had a special value-added tax regime, which allowed VAT to be accumulated in special accounts for producers' own needs. The situation had changed radically since January 1, 2016, when the amendments to the Tax Code came into force. In 2016, a differentiated system of special tax regimes by types of agricultural 
Tax burden...

products was introduced for agricultural producers (Table 2). Since 2017, the special regime has been abolished.

Table 2.

Distribution of VAT amounts according to the special regime in 2016

\begin{tabular}{lcc}
\hline \multirow{2}{*}{ Agricultural goods } & \multicolumn{2}{c}{ Directions for using VAT amounts } \\
\cline { 2 - 3 } & $\begin{array}{c}\text { Directed to special accounts of } \\
\text { agricultural enterprises, (\%) }\end{array}$ & $\begin{array}{c}\text { Transferred to the } \\
\text { state budget, (\%) }\end{array}$ \\
\hline $\begin{array}{l}\text { Cereals and industrial crops } \\
\text { Livestock products }\end{array}$ & 15 & 85 \\
$\begin{array}{l}\text { Other agricultural products and } \\
\text { services }\end{array}$ & 80 & 20 \\
\hline
\end{tabular}

This distribution of VAT had a significant negative impact on the performance of many Ukrainian enterprises specializing in crop production (cereals and sunflower), in 2016 they paid $85 \%$ of VAT to the budget, leaving $15 \%$ at their disposal.

The financial indicators of enterprises in the agricultural sector of the economy are shown in table 3 .

Table 3.

Financial indicators of agricultural enterprises of Ukraine in 2014-2019 (State Statistics Service of Ukraine, 2021)

\begin{tabular}{|c|c|c|c|c|c|c|}
\hline Indicators & 2014 & 2015 & 2016 & 2017 & 2018 & 2019 \\
\hline \multicolumn{7}{|l|}{$\begin{array}{l}\text { Financial results before } \\
\text { taxation, }\end{array}$} \\
\hline UAH million & 21677.4 & 103137.6 & 91109.5 & 69344.1 & 71478.5 & 94041.4 \\
\hline EUR million & 1129.0 & 3936.5 & 3208.1 & 2070.0 & 2254.8 & 3645.0 \\
\hline $\begin{array}{l}\text { Net profit (loss), UAH } \\
\text { million }\end{array}$ & 21481.3 & 102849.1 & 90613.2 & 68858.5 & 71002.6 & 93255.4 \\
\hline EUR million & 1118.8 & 3925.5 & 3190.6 & 2055.5 & 2239.8 & 3614.6 \\
\hline $\begin{array}{l}\text { Share of profitable } \\
\text { enterprises, }(\%)\end{array}$ & 84.1 & 88.4 & 87.7 & 86.2 & 86.3 & 83.1 \\
\hline $\begin{array}{l}\text { Profitability of } \\
\text { operating activities, }(\%)\end{array}$ & 20.6 & 41.7 & 32.4 & 22.4 & 18.3 & 19.2 \\
\hline
\end{tabular}

The most favorable year for agricultural enterprises was 2015. It was the last year when the special VAT regime was fully operational and the single tax rate was $0.45 \%$. In 2016 , the special regime was severely limited (Table 2), and the single tax rate increased to $0.81 \%$. As a result, profitability in the industry dropped from 41.7 to $32.4 \%$. In 2017, the special regime was completely abolished, and the single tax rate increased to $0.95 \%$, which led to a further decline in the profitability of agricultural enterprises. Although it should be noted that, according to statistics, even the profitability of agricultural enterprises is $19.2 \%$ - higher than in other sectors of Ukraine's economy. 
The abolition of the special VAT regime in 2017 was partially offset by the introduction of a budget VAT subsidy for agricultural enterprises that grew vegetables, fruits, berries, engaged in animal husbandry, etc. Since 2018, budget funds within this area of state support have not been allocated.

In 2020, Ukraine applies VAT rates of 20\%, 7\% and 0\% (Tax Code of Ukraine, 2021). However, in order to support the agricultural sector of the economy, the issue of taxation of agricultural products and foodstuffs at reduced rates has been repeatedly raised.

The practice of applying reduced VAT rates is common in the countries of the European Union and is aimed at ensuring the availability of food.

In accordance with Article 98 of Council Directive 2006/112 / EC (Council Directive, 2006) on the common system of value added tax, in order to prevent structural imbalances in the Community and distortions of competition in certain activities resulting from the application of different standard VAT rates by Member States, a minimum standard rate of $15 \%$ with the possibility of revision. The EU Member States may apply one or two reduced rates.

The provisions of the Directive also stipulate that the reduced rate should be set in such a way that VAT liabilities cover the existing tax credit and that there is no need for budgetary reimbursement of VAT amounts.

The reduced rates are set as an interest rate of the tax base, which cannot be lower than $5 \%$, but for some countries there are exceptions to certain goods, works and services. The countries that apply reduced rates for VAT on agricultural activities and their products are Poland (a reduced rate of $8 \%$ for agricultural products), Hungary (18\% for milk), etc.

Below we present the draft laws in this area, which in recent years have been registered in the Verkhovna Rada (Table 4).

Table 4.

Comparison of draft laws on the introduction of preferential VAT rates for the agricultural sector of the economy (Draft laws..., 2021)

\begin{tabular}{ll}
\hline \multicolumn{1}{c}{ Draft laws } & \multicolumn{1}{c}{ Substantive provisions } \\
\hline $\begin{array}{l}\text { Draft law № 7420 of 19.12.2017 "On } \\
\text { Amendments to the Tax Code of Ukraine to } \\
\text { reduce the value added tax rate for agricultural } \\
\text { enterprises" }\end{array}$ & $\begin{array}{l}\text { - reduction of the VAT rate on transactions for } \\
\text { the sale (supply) of agricultural products in the } \\
\text { customs territory of Ukraine from } 20 \text { to } 7 \\
\text { percent }\end{array}$ \\
\hline $\begin{array}{l}\text { Draft law № 7420-1 of 27.12.2017 "On } \\
\text { Amendments to the Tax Code of Ukraine to } \\
\text { reduce the value added tax rate for certain types } \\
\text { of agricultural products" }\end{array}$ & $\begin{array}{l}\text { - VAT taxation at the rate of 10\% of some food } \\
\text { and raw materials for their production, in } \\
\text { particular, livestock products, sugar beets, beet } \\
\text { sugar }\end{array}$ \\
\hline $\begin{array}{l}\text { Draft law № 7420-2 of January 3, 2018 "On } \\
\text { Amendments to the Tax Code of Ukraine to }\end{array}$ & $\begin{array}{l}\text { - VAT taxation at the rate of 10\% of some food } \\
\text { and raw materials for their production, in }\end{array}$ \\
$\begin{array}{l}\text { Reduce the Value Added Tax Rate for Certain } \\
\text { pypes of Agricultural Products" }\end{array}$ & $\begin{array}{l}\text { pagar, vegetables, wheat, flour, bakery products } \\
\text { sugar, }\end{array}$ \\
\hline $\begin{array}{l}\text { Draft law № } 8570 \text { of 07/06/2018 "On } \\
\text { Amendments to the Tax Code of Ukraine to } \\
\text { reduce the value added tax rate for }\end{array}$ & $\begin{array}{l}\text { - VAT taxation at the rate of 7\% supply and } \\
\text { import to Ukraine of trees, shrubs with edible } \\
\text { fruits, nuts, grapes, certain fruits }\end{array}$ \\
\hline $\begin{array}{l}\text { Draft law № 3656 of 15.06.2020 "On } \\
\text { Amendments to the Tax Code of Ukraine on }\end{array}$ & $\begin{array}{l}\text { - establishment of a reduced rate of value added } \\
\text { tax - 14\% on supply operations in the customs }\end{array}$ \\
\hline
\end{tabular}


Tax burden...

\begin{tabular}{ll}
\hline $\begin{array}{l}\text { the Value Added Tax Rate on Transactions for } \\
\text { the Supply of Certain Types of Agricultural }\end{array}$ & $\begin{array}{l}\text { territory of Ukraine and import into the customs } \\
\text { territory of Ukraine of certain types of } \\
\text { agricultural products }\end{array}$ \\
\hline
\end{tabular}

The need for such draft laws is justified as follows:

- it is necessary to provide state support to the agricultural sector of the economy in the conditions of the abolition of the special VAT regime from 2017, to prevent mass bankruptcy of enterprises,

- it is necessary to additionally support the most vulnerable branches of agriculture, in particular, animal husbandry, horticulture,

- it is necessary to take measures to stop the growth of food prices, to ensure the optimal structure of food consumption (increase in consumption of fruits, meat and dairy products),

- it is necessary to bring out the "shadow" producers who are forced to hide income due to excessive tax burden,

- it is necessary to counteract the competition of agricultural producers from other countries, in particular, the countries of the European Union after the conclusion of the Association Agreement with the EU.

In our opinion, the application of preferential VAT rates for the agricultural sector has the following advantages and disadvantages.

Advantages:

- development of agricultural enterprises, increase of investments,

- reduction of prices for agricultural products, improvement of its accessibility for the population,

- reduction of the effectiveness of a number of tax evasion schemes, de-shadowing of agricultural production,

Disadvantages:

- reduction of tax revenues to the budget,

- transfer of the tax burden to other sectors of the economy, violation of the principles of fair taxation,

- complications of tax administration,

- emergence of new schemes of tax evasion.

Draft law № 3656 was adopted on December 17, 2020 and is expected to be signed by the President of Ukraine. After passing all the necessary procedures, the Tax Code will be amended, according to which the rate of $14 \%$ will be applied to operations on supply in the customs territory of Ukraine and import into the customs territory of Ukraine of the following products: cattle, pigs, wheat, rye, barley, oats, corn, soybeans, flax seeds, rapeseed and rape, sunflower, other oilseeds, sugar beets.

The authors of the draft law noticed (Website of the Verkhovna Rada of Ukraine, 2020):

- reduction of the VAT rate on most transactions will not lead to budget losses, as these goods are not sold to the final consumer who is the actual VAT payer,

- not only agricultural producers but also processors will benefit from the reduction of the VAT rate, as the term of payment of the basic amount of VAT for them is moved from the date of payment of raw materials to the date of payment of obligations for sales of its products (at least 30 days), 
- when reducing the VAT rate on transactions for the sale of grain and oilseeds, the amount of compensation from the budget to exporters is reduced proportionally. That is, budget expenditures and risks of losses associated with VAT fraud and the use of the so-called "twists" are reduced, as the effectiveness of such fraudulent schemes is sharply reduced. Draft law №3656 has been widely criticized. The main claims to it from scientists and practitioners are as follows:

- reduction of tax credit amounts for processing enterprises purchasing agricultural products, deterioration of their financial performance,

- the amount of budgetary compensation to exporters will decrease,

- prices for final foodstuffs will not decrease, because the VAT rate on them has remained at the level of $20 \%$,

- lack of support for sorghum, buckwheat, peas, a number of other products,

- due to the increase in the number of rates, the administration of VAT will become more difficult, the control work of the State Tax Service will be less efficient, and bureaucratic pressure will increase.

The introduction of a tax on withdrawn capital can significantly affect the taxation of agricultural producers (Draft law №8557) (Draft laws on the website, 2021).

Its purpose is to free up funds for the development and modernization of enterprises and stimulate economic growth by taxing only that part of the profits of enterprises that is not aimed at expanding or creating the production. This approach is applied in the Republic of Estonia, the Republic of Latvia and Georgia.

The transformation of the income tax into a tax on withdrawn capital is supported, in particular, by the Association of Taxpayers of Ukraine, the Ukrainian Institute of the Future, members of the coalition "For De-Shading the Economy", the Public Council at the State Fiscal Service of Ukraine.

The draft law provides for the replacement of the corporate income tax with a tax on withdrawn capital. The object of taxation of the withdrawn capital tax is defined as operations on withdrawal of capital and operations equated to operations on withdrawal of capital. Taxpayers of withdrawn capital are expected to identify residents (business entities - legal entities that conduct business activities both in Ukraine and abroad) and non-residents (legal entities and their permanent establishments that conduct activities on the territory of Ukraine).

The draft law proposes to apply the following rates of tax on withdrawn capital:

- $15 \%$ - to capital withdrawal operations,

- $20 \%$ - to operations equated to capital withdrawal operations (except for operations taxed at a rate of $5 \%$ ),

- $5 \%$ - to the funds paid for the fulfillment of debt obligations to related parties - nonresidents (under certain conditions) (Draft laws on the website, 2021).

With the adoption of this draft law, the tax burden on enterprises will be reduced, and many agricultural enterprises will have an incentive to abandon the simplified taxation system.

The gradual growth of profitability of agricultural enterprises in Ukraine is an indicator of economic development of rural areas, increasing the efficiency of land use and sustainable development of the country's export potential. At the same time, improving the efficiency of the rural economy requires new fair approaches to the distribution and redistribution of established funds of agricultural enterprises. 
Tax burden...

Thus, the mechanism of accrual and distribution of taxes has to perform important tasks illustrated by the study:

- formation of the fiscal burden on the agricultural producer,

- creating conditions for the accumulation of financial resources during peak periods of costs,

- filling the revenue side of local budgets with monetary resources,

- implementation of instruments of indirect state support to rural areas and agricultural enterprises.

Thus, in the system of formation and distribution of the tax burden, contradictions and the need for cooperation between the state, local authorities and agricultural producers are formed. The development and implementation of fair and effective mechanisms for taxation and distribution of taxes between levels of government remains a promising area of new research.

\section{Conclusions}

The largest part of the tax burden of agricultural enterprises is formed by the following taxes, fees, mandatory payments:

- single tax (group IV),

- VAT,

- taxes on the salary fund (personal income tax, military duty, single contribution to compulsory social insurance),

- corporate income tax,

- land tax.

Recent changes in legislation aimed at reforming the tax system in accordance with the requirements of the International Monetary Fund, reduce the amount of state support for agricultural enterprises, increase their tax burden, which will negatively affect their activities.

It is expedient to introduce preferential VAT rates for agricultural enterprises and a tax on withdrawn capital.

\section{References}

Alm, J., El-Ganainy, A. (2013). Value-added taxation and consumption. International Tax and Public Finance, 20(1), 105-128.

Baranova, V., Dubovik, O. (2013). The impact of the tax burden on business development. Scientific Bulletin of the National University of the State Tax Service of Ukraine (Economics, Law), 1(60), 25-30.

Council Directive 2006/112 / EC of 28 November 2006 on the common system of value added tax https://eur-lex.europa.eu/eli/dir/2006/112/oj, (accessed on 2021/01/28).

Demyanenko, M. (1999). Reforming tax relations in the agricultural sector of agriculture. Economics of AIC, 6, 78-80.

Draft laws on the website of the Verkhovna Rada of Ukraine http://w1.c1.rada.gov.ua/pls/zweb2/ webproc2 (in Ukrainian), (accessed on 2021/01/28).

Halushchak, I., Kokhan, I., Dmytrovska, V. (2019). Features of Tax Policy in Ukraine in the Context of European Integration Online Journal Modelling the New Europe, 31, 90-103. 
Hogan, L. (2012). Non-renewable resource taxation: policy reform in Australia. Australian Journal of Agricultural and Resource Economics, 56(2), 244-259. doi.org/10.1111/j.1467-8489.2012.00583.x

Kostornoi, S. (2014). Directions of reforming the taxation of agricultural enterprises. Collection of scientific works of the Tavriya State Agrotechnological University (economic sciences), 2. 110-113.

Kovalenko, N., Hutsol, T., Kovalenko, V., Glowacki, S., Kokovikhin, S., Dubik, V., Mudragel, O., Kuboń, M., Tomaszewska-Górecka, W. (2021). Hydrogen Production Analysis: Prospects for Ukraine. Agricultural Engineering,25(1), 99-114.

Kovalenko, N., Kovalenko, V., Hutsol, T., Ievstafiieva, Y., Polishchuk, A. (2021a). Economic Efficiency and Internal Competitive Advantages of Grain Production in The Central Region of Ukraine. Agricultural Engineering, 25(1), 51-62.

Krysovaty, A., Vasylevska, G. (2013). The latest paradigm of preferential taxation. Kyiv: Center for Educational Literature.

Laffer, A., Seymour, J. (1979). The Economics of the Tax Revolt. New York: Harcourt Brace Jovanovich

McGee, R.W. (2008) Taxation and public finance in transition and developing economies. New York: Springer Science \& Business Media.

Odintsov, O., Yevtukhova, T., Vasylkonova, E., Kunchenko-Kharchenko, V. (2020) Influence of tax burden on economic development of agricultural enterprises in Ukraine Journal of Eastern European and Central Asian Research, 7, 150-162.

Prokopchuk, E. (2014). Features of the transformation of the special regime of VAT collection in the field of production and processing of agricultural products. Prospects for Science and Education, 4(10), 167-173.

Rymanov, A. (2017). Differential land rent and agricultural taxation. Agricultural Economics (Zemédělská ekonomika), 63(9), 421-429.

Shevchuk, V., Kopych, R. (2018). Assessing Fiscal Sustainability in Ukraine: TVP and VAR/VEC Approaches. Entrepreneurial Business and Economics Review, 6(3), 73-87.

Siroky, J., Krajcova, J., Hakalova, J. (2016). The taxation of agricultural land with the use of multicriteria analysis. Agricultural Economics-Czech, 62, 197-204.

Slemrod, J. (1990). Optimal taxation and optimal tax systems. Journal of economic Perspectives, 4(1), 157-178.

State Statistics Service http://www.ukrstat.gov.ua (in Ukrainian), (accessed on 2021/01/28).

Tax Code of Ukraine https://zakon.rada.gov.ua/laws/show/2755-17 (in Ukrainian), (accessed on 2021/01/28).

Troilo, M., Zdziarski, M., Collins, J. M. (2017). Competitiveness, Technology Licensing, and Ease of Paying Taxes: A 30-Country Study. Entrepreneurial Business and Economics Review, 5(4), 11-34.

Trusova, N., Synchak, V., Borovik, L., Kostornoi, S., Chkan, I., Forkun, I. (2020). Fiscal policy in a decentralized space of the financial system of Ukraine. International Journal of Criminology and Sociology, 9, 2891-2904.

Tryhuba, A., Hutsol, T., Glowacki, S., Tryhuba, I., Tabor, S., Kwasniewski, D., Sorokin, D., Yermakov, S. (2021). Forecasting Quantitative Risk Indicators of Investors in Projects of Biohydrogen Production from Agricultural Raw Materials. Processes 2021, 9(2), 258.

Tryhuba, A., Hutsol, T., Tryhuba, I., Pokotylska, N., Kovalenko, N., Tabor, S., Kwasniewski, D. (2021). Risk Assessment of Investments in Projects of Production of Raw Materials for Bioethanol. Processes 2021, 9(1), 12.

Tsap, V. (2018). Control of the tax burden on taxpayers by regulatory authorities. Collection of scientific works of the Tavriya State Agrotechnological University (economic sciences), 2(37), 236-242. 
Tax burden...

Tulush, L. (2016). Tax reform in agriculture: risks and prospects. Collection of scientific works of Uman National University of Horticulture. 88(2), 20-33.

Uryszek, T. (2018). Fiscal Sustainability of Local Governments in the Visegrad Group Countries. Entrepreneurial Business and Economics Review, 6(3), 59-71.

Vasiljevic, Dusan (2016). Taxation of agricultural and forest land: Comparative perspective and practice in Serbia. Ekonomika poljoprivrede, 63(2), 713-726.

Wach, K. (2006). Systemy podatkowe krajów Unii Europejskiej. Wolters Kluwers Polska, Kraków. ISBN: 83-7484-030-7.

Yatsukh, O. (2015). Ways to optimize the tax burden for business entities in the agricultural sector of Ukraine. Collection of scientific works of Tavriya State Agrotechnological University. (Economic sciences). 1(29), 187-191.

Zhuk, V. (2011). Status and development of special tax regimes for agrarian business. Finance of Ukraine, 7, 33-42.

\section{OBCIĄŻENIE PODATKOWE PRZEDSIĘBIORSTW ROLNYCH NA UKRAINIE}

Streszczenie. Rolnictwo jest jednym z wiodących sektorów gospodarki Ukrainy, a państwo przywiązuje szczególną wagę do jego rozwoju. Jednym z kierunków wsparcia państwa dla rolnictwa jest realizacja preferencji podatkowych, dzięki czemu przedsiębiorstwa rolne mają mniejsze obciążenia podatkowe. Optymalny poziom obciążeń podatkowych jest ważnym czynnikiem zapewniającym pozytywną dynamikę działalności gospodarczej w rolnictwie, a także stabilność społeczno-polityczną. Celem artykułu jest określenie wpływu ostatnich zmian w prawie podatkowym Ukrainy na obciążenia podatkowe przedsiębiorstw rolnych, a także ewentualnego wpływu aktualnych projektów ustaw. W artykule omówiono cechy ustawodawstwa podatkowego Ukrainy w zakresie opodatkowania producentów rolnych i jego zmian w ostatnich latach - podwyższenie jednolitej stawki podatkowej, wprowadzenie indeksacji regulacyjnej wyceny pieniężnej gruntów, zniesienie specjalnego reżimu podatku od wartości dodanej . Rozważono zalety i wady stosowania uproszczonego systemu opodatkowania przez przedsiębiorstwa rolne. W artykule rozważono obszary poprawy opodatkowania przedsiębiorstw rolniczych, zmierzające do zmniejszenia obciążeń podatkowych przedsiębiorstw rolniczych, w szczególności zastosowanie obniżonych stawek podatku od towarów i usług, wprowadzenie podatku od wycofanego kapitału zamiast podatek dochodowy. Wyniki badania to rekomendacje dla przedsiębiorstw rolniczych dotyczące wyboru systemu podatkowego o najniższym obciążeniu podatkowym, a także rekomendacje dotyczące usprawnienia ustawodawstwa podatkowego Ukrainy.

Słowa kluczowe: podatki, obciążenia podatkowe, producenci rolni, uproszczony system podatkowy, podatek jednolity (grupa IV) 